\title{
Development Trends in the Crop Production in Slovakia after Accession to the European Union-Case Study, Slovakia
}

\author{
Jana Némethová ${ }^{1, *(1)}$ and L'ubomír Rybanský ${ }^{2}$ (1) \\ 1 Department of Geography and Regional Development, Faculty of Natural Science, Constantine the \\ Philosopher University in Nitra, 94901 Nitra, Slovakia \\ 2 Department of Mathematics, Faculty of Natural Science, Constantine the Philosopher University in Nitra, \\ 94901 Nitra, Slovakia; lrybansky@ukf.sk \\ * Correspondence: jnemethova@ukf.sk
}

check for updates

Citation: Némethová, J.; Rybanský,

L'. Development Trends in the Crop

Production in Slovakia after

Accession to the European

Union-Case Study, Slovakia.

Sustainability 2021, 13, 8512. https://

doi.org/10.3390/su13158512

Academic Editor: Roberto Mancinelli

Received: 7 June 2021

Accepted: 26 July 2021

Published: 30 July 2021

Publisher's Note: MDPI stays neutral with regard to jurisdictional claims in published maps and institutional affiliations.

\begin{abstract}
The development of agriculture in Slovakia in the last three decades has been influenced by two events: the transformation of agriculture after 1989 and Slovakia's accession to the European Union in 2004. In this paper, we analyze the effects of Slovakia's accession to the European Union on the development and structure of crop production. The aim of the paper was to identify connections, parallels and differences between the developments of the sown areas of the most important crops at the level of Slovakia and its regions in the period 2004-2020. Cluster analysis based on the similarity of the development of the sown areas divided the crops into four clusters (cereals; sugar-beet; oilseeds, multiannual fodder crops, maize; legumes, vegetables, potatoes). Multivariate analyses of the time series of sown areas also revealed similarities and differences between the regions of Slovakia. The results of the analysis point to regional differentiation and the identify two clusters. The first cluster comprises the Nitra and Trnava Regions, while the second cluster consists of the remaining six regions. The study has shown that changes in the agrarian sector after 2004, conditioned by Slovakia's accession to the European Union, have been reflected in changes in the area and structure of cultivated crops, and in the differentiated development of sown areas.
\end{abstract}

Keywords: development; crop production; size of sown areas of crops; similarity; cluster analyses; regions; Slovakia

\section{Introduction}

After Slovakia's accession to the European Union (EU) in the year 2004, Slovakia's agricultural sector started to adapt to the EU's Common Agricultural Policy (CAP) and the conditions of the common European market. On the one hand, Slovakia's agriculture is supposed to be competitive on the common EU market; on the other hand, the conditions for the farmers are not the same in all EU countries [1]. After Slovakia entered the EU, its agriculture was mainly affected by a lower level of subsidies compared to the original EU-15 member states. All of these conditions, along with opening the borders and the free movement of goods and services, put the farmers into an unfavorable position in comparison with the other EU-15 countries. This development resulted in a gradual decline in the individual sectors of agricultural production in Slovakia. Crop production and livestock production were not able to compete with the less expensive imported groceries and products, which benefited from a higher level of direct payments on the EU market. It is the country's priority to close the gap created by different levels of direct payments. This would strengthen the competitiveness of the farms and of the home market, and it would foster local production as well.

Although the accession of the Slovak Republic (SR) to the EU has opened up a large European agrarian market for farmers, it has also removed all protective barriers to the domestic market. The problems of finding a foothold on domestic and foreign markets and the economic crisis have been reflected in a decline in the number of farms. In the 
market agrarian space, stronger and larger enterprises, which appear to be more stable, are asserting themselves [1,2]. Since the accession of the Slovak Republic to the EU, agriculture has not yet experienced a significant change in orientation towards the efficient use of domestic production and the growth of competitiveness in order to succeed in the liberalized European market [3]. In the Accession Treaty, the new Member States negotiated the possibility of supplementing European subsidies from national budgets. Slovakia does not make full use of this possibility, which reduces its competitiveness and encourages the expansion of foreign products on the Slovak market [4]. The support provided by EU funding represents a significant share in the revenues of agricultural enterprises. According to the authors Jankacká and Lincényi [5], without the subsidies, Slovakia's agriculture would make significant losses. The support for agricultural production in the form of direct payments increases every year, and more than $80 \%$ of the funding is allocated to crop production [6]. The EU's Common Agricultural Policy encouraged farmers to attenuate livestock production and to specialize more in crop production, in particular the growing of large area crops. From these, they grow mainly cereals and oil-plants, whose production process can be managed by means of mechanisms and a small number of workers [7]. According to Bičík and Jančák [8], such specialization of crop production may endanger the economy of agricultural entities. On the other hand, the development of sown areas in Slovakia shows that farmers are able to react relatively quickly to changing market demands, and introduce crops with higher market demand into the crop production structure. The importance of crop production in Slovak agriculture has been increasing since EU accession, and the share of livestock production has been decreasing significantly, which is linked to a reduction in the number of livestock species (mainly pigs and cattle). Since 2009, crop production has dominated over livestock production in Slovakia. The share of crop production in the total gross agricultural output is currently 60\% [9]. According to Věžník et al. [10], Svobodová [11], Szabo et al. [4] and Scriecia [12], similar trends of development in agricultural production are also occurring in other new member states (e.g., Czechia, Hungary, Romania) following EU accession. Additionally, according to Chrastinová et al. [13], the structure of agricultural production in most EU regions, except for Great Britain, Austria and Poland, is dominated by crop production over livestock production. According to Lacko-Bartošová and Buday [14], Slovakia's agriculture has been going through a difficult period of evolution in recent years. At first, it faced a period of recession, and at present we are witnessing the stagnation of key economic and production factors. The increasing pressure on natural resources due to the growing global population confirms the importance of a strategy of sustainable development in agriculture. According to authors, sustainable agriculture is the main foundation of long-term economic growth, ensuring the employment of the rural population $[15,16]$.

The Common Agricultural Policy of the EU has a very significant impact on the current form, intensity and distribution of agricultural production in the EU countries, and therefore also in Slovakia. Thus, the first objective of the paper was to analyze the development and structure of crop production in Slovakia after 2004, and to find out which of the selected agricultural crops (cereals, grain maize, oilseeds, legumes, potatoes, sugar-beet, vegetables and multiannual fodder crops) had similar developmental impacts on the sown areas after accession to the European Union at the level of Slovakia. The second objective of the paper was to identify the similarity of the Slovak regions in terms of the development of the sown areas for the selected eight crops in the period 2004-2020.

The analysis of the similarity of spatial objects (countries, regions, etc.) in terms of different indicators is possible by comparing them at a specific time (e.g., Fanelli [17-19] in his papers uses hierarchical clustering methods in combination with the principal components method or factor analysis) and for a specific year at the level of EU countries and regions or Chrastinová et al. [13] worked with the average values of indicators for the period under study. By taking into account the temporal evolution of indicators, for example, Jäntschi, L. et al. [20] used a hierarchical method of time series clustering to analyze the evolution of different crop cultivations in the period 1990-2004 in Romania using a raw data-based approach. In this 
paper, we analyze the similarity between the time series of the sowing areas of the most important crops at the level of the Slovak Republic via clustering time series analysis and the similarities in the evolutions of the sowing areas in the regions of the Slovak Republic for the selected agricultural crops, via multivariate time series clustering analysis, respectively.

Since there are no research works in the academic sphere focused on the evaluation and analysis of agricultural production in Slovakia at different hierarchical levels, employing statistical methods aimed at the analysis of the time series of various indicators via clustering methods of multivariate statistics, we decided to approach this problem, which would be beneficial not only for the academic community but also to social practice.

The consequences of the transformation of agriculture in the 1990's and Slovakia's entering of the EU in the year 2004 were reflected in a change in the extent of the cultivation areas of agricultural crops. In a significant way, they influenced the use of agricultural land. According to Lazíková et al. [21], only crop diversity, as opposed to a unilateral focus on crop production of cereals and oil-plants, plays an important role in sustainable agrosystems. The impact of the payments under the EU's CAP affects the heterogeneity of the crops grown by agricultural enterprises. In Slovakia, there are regional disparities with regards to crop diversity. It is typically the regions with the best soil quality that have the highest degree of crop diversity in the southwestern part of Slovakia, which is being influenced, for example, by the legal form of agricultural enterprises, the distance of the enterprise from a town, the education of the managers, etc.

It is not only Slovakia's agrarian sector that has undergone major structural changes over the past 30 years. This is also true of the agrarian sectors of other European countries. In the Czech Republic, not only did the structure of crop production change, but the cultivation areas and the production of several crops also decreased [10,22,23]. According to Kroupová and Trnková [24], differentiation in the production competencies of Czech farmers (focusing on crop production) is significantly affected by objective factors, such as the size of the agricultural entity, the given hectare yield of the crop, the number of workers, and the natural conditions. Kotyza and Slaboch [25] observed interesting results in their work, referring to the impact of the EU's CAP on crop production. They analyzed the degree of self-sufficiency of the Czech Republic and Poland in the production of selected commodities-cereals, oil-plants, maize and potatoes. With the majority of the aforementioned commodities, the trend in self-sufficiency is either stable or growing. However, the Czech Republic (CR) is losing its self-sufficiency in potato production due to the reduction in cultivation areas. Slovakia ranks among the countries that are not self-sufficient in the basic commodities of crop production. This situation deteriorated after Slovakia's accession to the EU. The farmers were not capable of competing with the prices of imported food when they entered the common European market. The principal reason for this is that Slovakia's agrarian sector is significantly underfunded by the state budget. At present, Slovakia is only self-sufficient in the growing of cereals and sugar-beet. According to Todorová [26], the accession of Bulgaria to the EU significantly affected the famers' revenues. The revenues of the farmers dealing with the cultivation of cereals went up, while the entities growing vegetables, fruits and vines recorded a decrease in their sales figures. Skarżyńska et al. [27] dealt in their paper with the issue of the impact of the rising costs on the profitability of crop production in Poland.

Due to the impact of the EU's CAP, the production function of agriculture has taken a backseat, and the importance of landscape architecture and environmental protection has grown. This is the transition from productivism to post-productivism [10]. In line with the aforementioned trends, apart from producing food, the farmer is supposed to fulfil several other necessary functions, such as landscape design, ecology, environmental protection, etc. Other authors such as Maye [28], Nazzaro and Marrota [29] also carried out an analysis of agricultural multifunctionality in the context of food safety and climate change linked to the alternations in soil exploitation. In accordance with the evolution of the EU's CAP, the effort to assess the individual preconditions for agricultural revitalization, the reinforcement of the non-production function, and the possibilities for rural development have come 
increasingly to the fore, according to Spišiak et al. [30], Shucksmith et al. [31], Râmniceanu and Ackrill [32] and Rizzo [33]. Sadowski and Czubak [34] analyzed selected priorities in the development of agriculture and rural areas in EU countries. Konečný [35] stressed the importance of the multifunctionality and spatial polarization of agriculture in CR. The conclusions of the paper hint at the increasing territorial polarization of agriculture during Czechia's integration into the EU among regions with different natural conditions. However, it is becoming evident that while the fertile lowlands gradually specialize in crop production, spatial polarization in livestock production is increasing as a result of the growing importance of montane regions. According to Hrabák [36], the European model of agriculture, based on the concept of multifunctional agriculture, has been applied in CR since its accession to the EU. The author deals with agricultural multifunctionality and the impact of applying this concept in the light of the protection of the environment and the landscape in these regions. According to Greslová et al. [37], agricultural production in Czechia and Poland began to increase because of the states' entering the EU in 2004. The area of agricultural land fell by approximately $20 \%$, and the production of crops shifted to more fertile regions, while agricultural land was abandoned in less favorable areas. The process of abandoning land is not only affected by the transformation of agriculture, but also by the implementation of the EU's CAP. The succession processes occurred in Slovakia mainly as a result of agricultural stagnation, specifically in livestock production [38]. The abandonment of agricultural areas is a recent years social issue, and a problem of landscape ecology related to succession. This phenomenon has been observed over the past 20 (or perhaps even 40) years in the submontane regions in Slovakia, in zones with unfavorable conditions for agriculture [39].

\section{Material and Methods}

\subsection{Material}

In the paper we used statistical data from the Statistical Office of the Slovak Republic. The Statistical Office of the Slovak Republic collects data on crop production at the level of districts (LAU 1). However, we were able to perform our analyses up to the levels of regions (NUTS 3) and the territory of the whole country, respectively, given that in 33 districts of the overall 79 over the reference period 2004-2020, sugar-beet was grown in none of the years, and maize was grown in only 1 district (the Gelnica District). Besides this, in several districts there were years in which some of the crops were not sown or the data were unavailable due to individual data protection issues. The set of available data related to agricultural issues at the county and national level is more extensive and is updated annually. For the analysis, we chose the period 2004-2019 (2020), with 2004 being the year of Slovakia's accession to the EU, and the last years monitored being 2019 (2020), which are the most up-to-date years of available data.

\subsection{Methods}

The goal of clustering is to determine whether, in the data of naturally occurring groups, groups with similar development signs exist. In contrast to classification, it does not require a primary definition of classes, and therefore it is considered an unsupervised method. The groups (clusters) are formed in such a way that their elements are similar depending on the chosen measure; in other words, the formation attempts to minimize the intracluster variance and maximize the intercluster variance. This method is most commonly used for searching for patterns [40]. Most clustering techniques presuppose statistical data, from which it follows that the time series analysis requires a special approach. The common approach is to regard the length of time series $N$ as an observation with $\mathrm{N}$ items, and subsequently apply conventional clustering techniques. Another possible approach is to convert the similarity measure to a measure suitable for time series analysis. The conventional clustering methods are divided into five categories: partitioning, hierarchical, density-based, grid-based and model-based methods [41]. 
In the partitioning method, the given set of $n$ objects is divided into $k$ segments (partitions), so that each of them presents a cluster containing at least one object, while $k \leq n$. The partition can be crisp, if every object belongs to a single cluster, or it can be fuzzy, if a single object belongs to several clusters, but with different degrees of membership. The best known crisp partition methods are the $k$-means algorithm, wherein each cluster is represented by the average value of the objects in the cluster, and the k-medoids algorithm, wherein each cluster is characterized by the object that shows the smallest average dissimilarity from other objects in the cluster. Analogous algorithms for fuzzy partitions include fuzzy-c-means and fuzzy-c-medoids. The clustering procedures that are popular in the field are methods of hierarchical clustering, which group objects into a dendrogram (tree of clusters). In general, we differentiate between two types of hierarchical methods: agglomerative, in which the strategy of bottom-up clustering is being applied, and the divisive approach, which employs a top-down strategy. The disadvantage of hierarchical clustering is the fact that if an object is already categorized in a certain cluster, it can no longer be removed from it. This deficiency is compensated for by combining hierarchical clustering with another non-hierarchical clustering technique. The hierarchical clustering techniques are not limited to time series of equal length, and they are also applicable for time series of unequal length if an appropriate similarity measure is used for the calculation of the similarity matrix, such as dynamic time warping (DTW). Similar to statistical data clustering, time series clustering also requires a clustering algorithm or approach. The choice of the specific approach depends on the type of data and the purpose for which the output will be used. With the data themselves, it is possible to determine whether they acquire discrete or analogue values, or if the data are one-dimensional or multidimensional, by determining whether the time series is of equal or unequal length. Many different algorithms have been created for time series clustering. Regardless of their mutual differences, it can be stated that they all attempt to modify the already existing algorithms for statistical data clustering. This is carried out by either working directly with the data from the time series, or the time series data are converted to statistical data, and these are subsequently inserted into an existing algorithm for statistical data clustering. For time series clustering, we modified or directly used three out of the five principal categories of time series clustering - partitioning methods, hierarchical methods, and model-based methods. Unlike the clustering analysis analyzing non-temporal data in the case of the time series, it is necessary to take into account some invariances, which are inherent within them. The first is the invariance of shift, which arises when two time series are similar though mutually shifted. The second is the invariance of noise, which occurs when the time series are similar in shape but differently complex. The final, third invariance is the scale invariance, which occurs when two time series differ in length, but could be similar if one were shorter or the other longer.

Relatively recent partitioning methods of clustering include $k$-shape clustering [42], which, apart from grouping the time series into clusters on the basis of similarities, also creates new time series from the time series situated in these clusters, which helps to characterize the cluster. Similarly to the k-means method, this is an iterative procedure. Unlike other clustering methods, $k$-shape clustering uses the so-called shape-based distance (SBD) designed by [42] in defining the centroid of each cluster and assigning a member to a cluster. The SBD is calculated as follows:

$$
\operatorname{SBD}(\vec{x}, \vec{y})=1-\max _{w}\left(\frac{\mathrm{CC}_{w}(\vec{x}, \vec{y})}{\sqrt{\mathrm{R}_{0}(\vec{x}, \vec{x}) \cdot R_{0}(\vec{y}, \vec{y})}}\right) .
$$

The SBD calculation uses the cross-correlation coefficient $\mathrm{CC}_{\mathrm{w}}(\overrightarrow{\mathrm{x}}, \overrightarrow{\mathrm{y}})$, which is the similarity measure of two sequences (time series): $\vec{x}=\left(x_{1}, x_{2}, \ldots, x_{m}\right)$ and $\overrightarrow{\mathrm{y}}=\left(\mathrm{y}_{1}, \mathrm{y}_{2}, \ldots, \mathrm{y}_{\mathrm{m}}\right) . \mathrm{R}_{0}(\overrightarrow{\mathrm{x}}, \overrightarrow{\mathrm{x}})$ and $\mathrm{R}_{0}(\overrightarrow{\mathrm{y}}, \overrightarrow{\mathrm{y}})$ are autocorrelations of the sequences $\overrightarrow{\mathrm{x}}$ and $\overrightarrow{\mathrm{y}}$. In order to allow for scale invariance, the time series are standardized in such a way that the average of the values representing the time series is 0 , and the standard value 
is 1 . In every iterative step, the objects in the cluster get updated along with the cluster centroids, until the similarities of all the objects to the new centroid are maximized. The $k$ value is not known beforehand. It is defined in such a way that, for several different $k$ values, the clustering procedure is performed, and on the basis of internal validity, the optimal value of the number of clusters is selected.

At present, there are a number of metrics suitable for determining the dissimilarity between a pair of time series, such as DTW (dynamic time warping), DBA (dynamic time warping Barycenter averaging), SBD (shape-based distance), KSC (K-spectral centroid clustering), GAK (global alignment kernel distance), and soft-DTW, a detailed description of which can be found in Sardá-Espinosa [43]. Several studies, e.g., Aghabozorgi et al.'s [44], showed that no best index of internal cluster validity exists. Therefore, we decided to use seven internal cluster validity indices (CVIs), which are directly accessible in the dtwclust library (Sarda-Espinosa [45]): silhouette (Rousseeuw [46]), to be maximized (sil); the Dunn index (Arbelaitz et al. [47]), to be maximized (D); the Calinski-Harabasz index [47], to be maximized (CH); score function [48], to be maximized (SF); the COP index [47], to be maximized (COP); the Davies-Bouldinov index [47], to be minimized (DB); the modified Davies-Bouldinov index [49], to be minimized (DBstar). All the calculations were carried out in the R programme R Core Team [50] with the use of the libraries dtwclust [45] and ggplot2 [51]. For cartographic visualization of the main reference crop production index, the development of sown areas, we applied the methods of thematic cartography and comparative data analysis, focusing on inter-year comparison and index comparison at the level of Slovak regions.

\section{Results and Discussion}

\subsection{Structure of Crop Production and Similarity of Temporal Development of Sown Areas of Selected Crops at the Level of SR}

The utilization of agricultural land in SR in the 2004-2017 period is characterized by a decrease in the acreage of the individual types of land. The downward trend in the size of agricultural land has been persistent since the year 1990. Since the year 2004, the decreasing trend in agricultural and arable land has been attenuated. The area decreased by only $1 \%$. A greater decrease has been seen in the area of permanent crops $(-18.4 \%)$. Conversely, permanent grasslands recorded a moderate increase of $1 \%$. The biggest drop in permanent crops was caused by the conversion of fruit groves into grasslands $[52,53]$. Of the total soil in Slovakia, agricultural land occupies roughly $50 \%$, and of this, arable land occupies $70 \%$, permanent grasslands $27 \%$, and permanent crops only $3 \%$. According to Zaušková et al. [38], the overall reductions in areas of individual categories of agricultural land are partly caused by the EU's CAP, mainly because of multifunctional agriculture, which implies the possibility of carrying on with the agricultural use of land without the obligation to produce on this soil. The CAP reform in 2003 cut the hitherto valid connection between direct payments and agricultural production, and applied the so-called decoupled payments, which dissolved the connection between subsidies and production [54].

Slovakia ranks among the countries that are most orientated towards agriculture. It is characterized by a high rate of ploughing $(70 \%)$, but also a high quality of agricultural land. Over the last decade, though, Slovakia has been tackling issues related to the commodity structure of crop production. Since Slovakia entered the EU, the structures of crop production have started to change in favor of cereals and some technical crops, especially oil-plants. By contrast, the production of several crops, such as potatoes, vegetables, fruit and grapes, went down [55]. The development of the sown areas in 2004-2020 at the level of SR was not found to be consistent when we examine the monitored crops (Figure 1). 


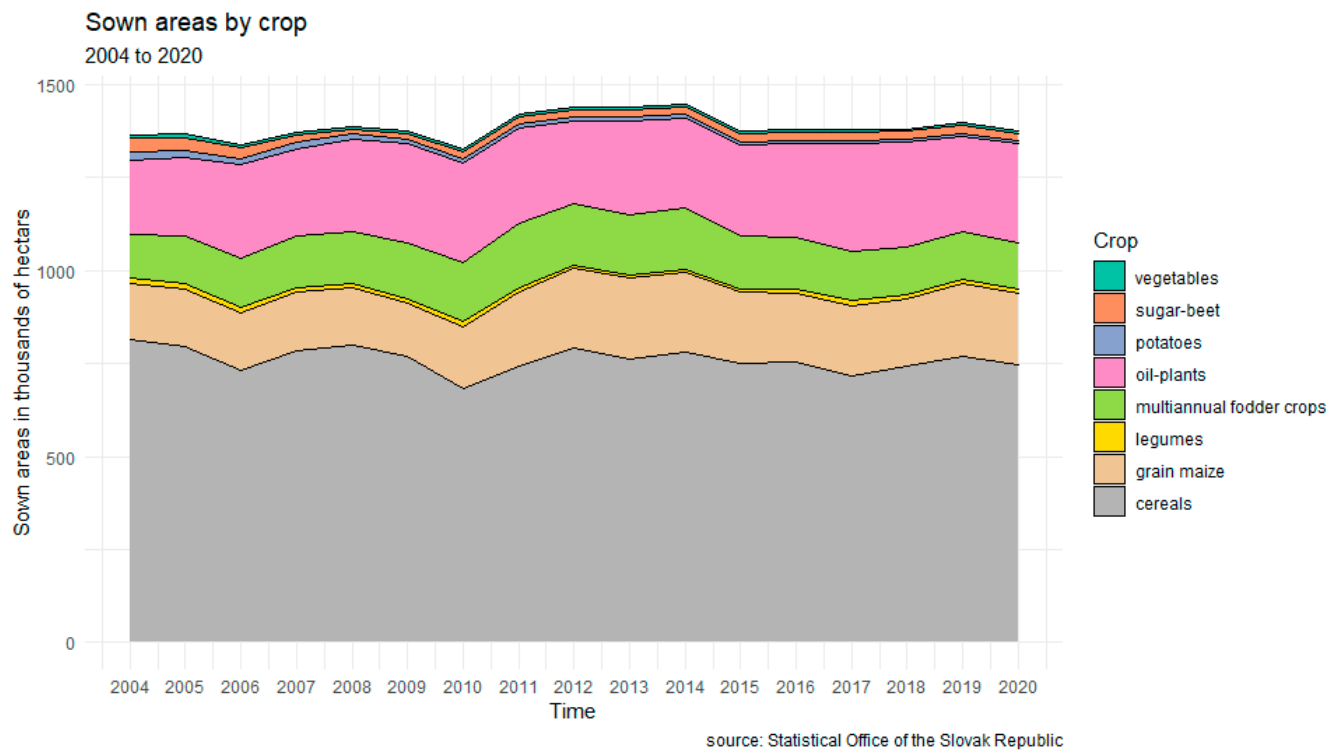

Figure 1. Development of sown areas of selected crops in SR in the years 2004-2020 (in ha). Source: [56]; authors' own research.

We analyzed the similarities in the temporal development of the sown areas of the eight selected crops (cereals, grain maize, oil-plants, legumes, potatoes, sugar-beet, vegetables and multiannual fodder crops) at the level of SR over the 2004-2020 period by means of the clustering methods, which suit this type of data (Figure 2). The most suitable values of internal validity indices ( $\mathrm{sil}=0.21, \mathrm{SF}=0.55, \mathrm{CH}=4.37, \mathrm{DB}=0.50, \mathrm{DBstar}=0.66, \mathrm{D}=0.53$, $\mathrm{COP}=0.21$ ) were obtained via the four-cluster solution by the k-shape clustering procedure with the SBD metric. The membership of the crops in the clusters is expressed in Figure 2 by the coloration of the time series. We categorized the monitored crops into four clusters based on sown area development.
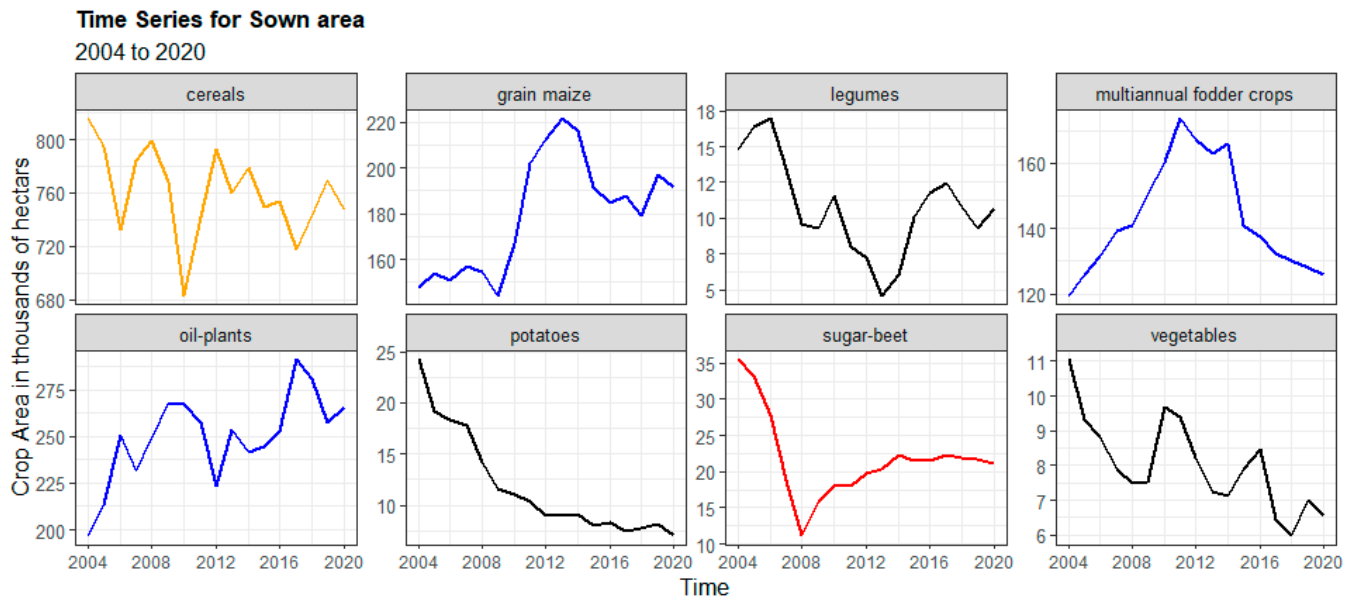

source: Statistical Office of the Slovak Republic

Figure 2. Time series of sown areas of crops at the level of SR over the period 2004-2020. The time series are color-coded according to cluster membership. Source: [56]; authors' own research.

The first cluster contains only one object-cereals. When it comes to cereal growing, Slovakia has a long tradition. This is because the soil and climate conditions are especially suitable for the cultivation of wheat and barley. Over the 2004-2020 period, a moderate drop in the acreage of cereals $(-8,4 \%)$ was recorded. Cereals occupy the largest share in arable land (up to $60 \%$ ). The development of the sown areas in the cluster points to a tendency of reducing the acreage of cereals, which can also be attributed to the ongoing 
decline in livestock production as a result of agricultural transformation and the adoption of the EU's CAP. Before 2004, livestock production was at two thirds of the rate of total cereal production.

Similar to cereals, sugar-beet forms a separate second cluster. The sown areas of sugar-beet in Slovakia dropped between 2004 and 2020 by approximately $41 \%$. The share of sugar-beet grown on arable land amounts to only $2 \%$. The changes in the sown areas of crop production were mainly due to some commodities being excluded from the subsidy scheme (e.g., sugar-beet or potatoes). The sown areas of these crops saw a significant fall, and in the case of sugar-beet, this meant a reduction in the processing capacity. Of the former ten sugar factories in Slovakia, only two operate today. Since 2008, the sown area of sugar-beet has been on the increase (Figure 2).

The third cluster is comprised of oil-plants, multiannual fodder crops and grain maize. These three crops saw an increase in sown areas from 2004 to 2011, which then gradually started to decrease. Oil-plants represent a very important group of crops, characterized by a permanent demand on the commodity market. Oil-plants are primarily used for producing energy, which is reflected in their relatively high share in the sowing structure of the crops grown. They occupy the second highest share, amounting to $16 \%$. The sown areas of oil-plants in 2020, in comparison with 2004, rose by up to $55 \%$. From oil-plants, mainly oilseed rape is cultivated; sunflower, poppy-seed and soya are grown on smaller sown areas. During the monitored period between 2004 and 2020, the sown areas of grain maize increased by approximately $33 \%$. At present, maize is an important crop for the production of ethanol, biogas and direct combustion material. Grain maize represents up to $10 \%$ of the sown areas of arable land in Slovakia. After Slovakia's accession to the EU, subsidy policies promoting the breeding of suckler cows proved positively effective. This support translated into an increase in the numbers of cattle, and also had a significant impact on the structure of crop production in Slovakia. In the segment of coarse fodder, the sown areas of multiannual fodder crops increased by approximately $10 \%$. Multiannual fodder crops grown on arable land are a valuable source of high-quality coarse fodder for farm animals. Their share in the structure of the crops grown is nearly $10 \%$.

A drop in representation in the sown areas over the monitored period is typical of the fourth cluster, which contains legumes, vegetables and potatoes. The opening up of Slovakia towards the European market brought about an inflow of potatoes and vegetables from other EU states. The farmers were not able to compete with the prices of foreign products, which caused a drop in the sown areas of these crops. The biggest drop among all the monitored crops, between 2004 and $2020(-69.2 \%)$, was recorded in potatoes. Several agricultural entities abandoned potato growing due to the insufficient financial support for the agrarian sector from domestic resources, the high production input costs, the obsolete technology of crop production, the higher labor costs, problems with storing the crops, etc. The share of potatoes in the sown structure only amounted to $1.8 \%$. In Slovakia, significant changes arose in terms of the distribution of potatoes, which were reduced in typically submontane areas. The growing of sugar-beet in the Slovak regions has also been reduced significantly [57]. Slovakia is becoming an importer of potatoes (mainly from Poland), despite having good production potential for their cultivation. The sown areas of legumes has moderately dropped by $14 \%$. In the sowing structure, they only account for $1 \%$. Vegetables also saw a considerable decrease in their sown areas $(-59.5 \%)$. The share of vegetables in the sown structure is very low, at only about $0.7 \%$. In the next years, it is therefore necessary to promote the growing of all kinds of vegetables, and increase the interest of Slovak consumers in vegetables cultivated in the growing regions of Slovakia.

\subsection{Similarities among Slovak Regions with Respect to the Development of Sown Areas of Selected Crops}

Before we deal with the similarities among Slovak regions in terms of the development of sown areas of selected crops (cereals, grain maize, oil-plants, legumes, potatoes, sugarbeet, vegetables and multiannual fodder crops) in this part of the paper, we shall point to the importance of individual regions in the growing of the aforementioned crops. The 
most favorable conditions for the growing of cereals are in Slovakia's lowlands, where we find the highest soil quality. One such region is the Nitra Region, which contains over $35 \%$ of the sown areas of cereals in Slovakia. The Trnava Region has a $22 \%$ share, and the Košice Region a 13\% share. The development of the sown areas of cereals in the individual regions of Slovakia in 2004, 2010 and 2019 is shown in Figure 3.

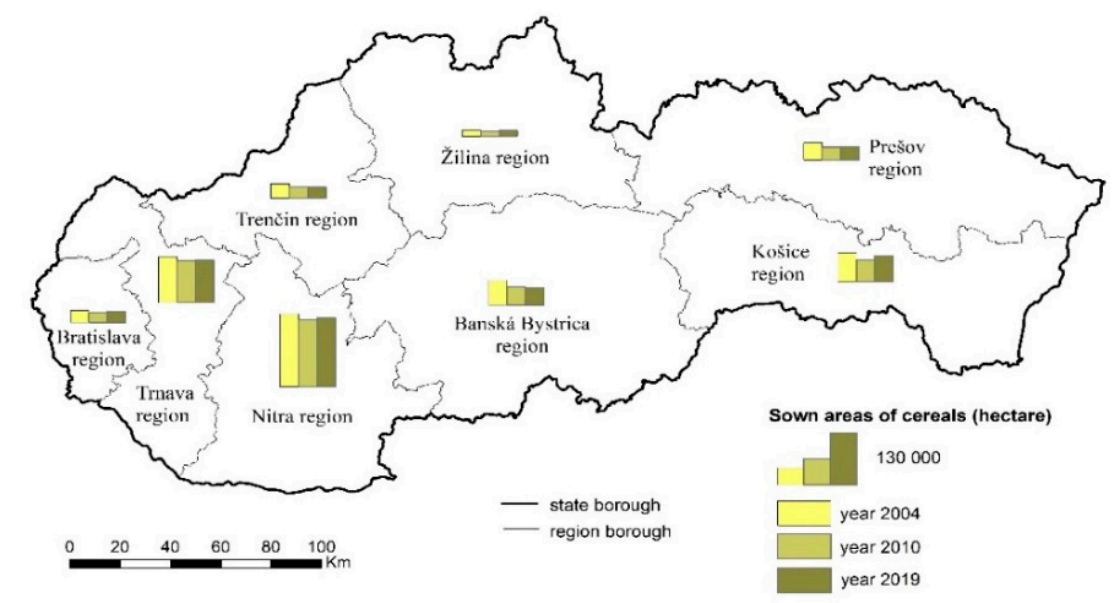

Figure 3. Development of sown areas of cereals in the regions of SR in 2004, 2010 and 2019 (in ha). Source: [56]; authors' own research.

The most suitable conditions for growing grain maize are in the regions of southern Slovakia (Figure 4). The Nitra, Trnava and Košice Regions together occupy an $80 \%$ share of Slovakia's sown areas. Oil-plants are also mostly grown in the southern regions of the country (Figure 5).

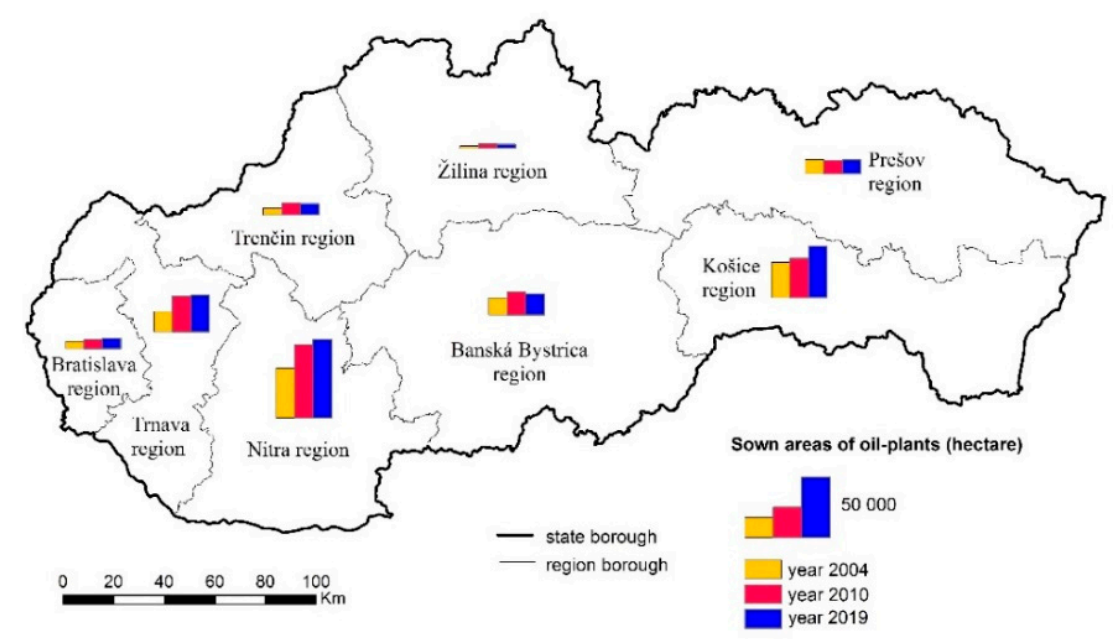

Figure 4. Development of sown areas of oil-plants in the regions of SR in 2004, 2010 and 2019 (in ha). Source: [56]; authors' own research. 


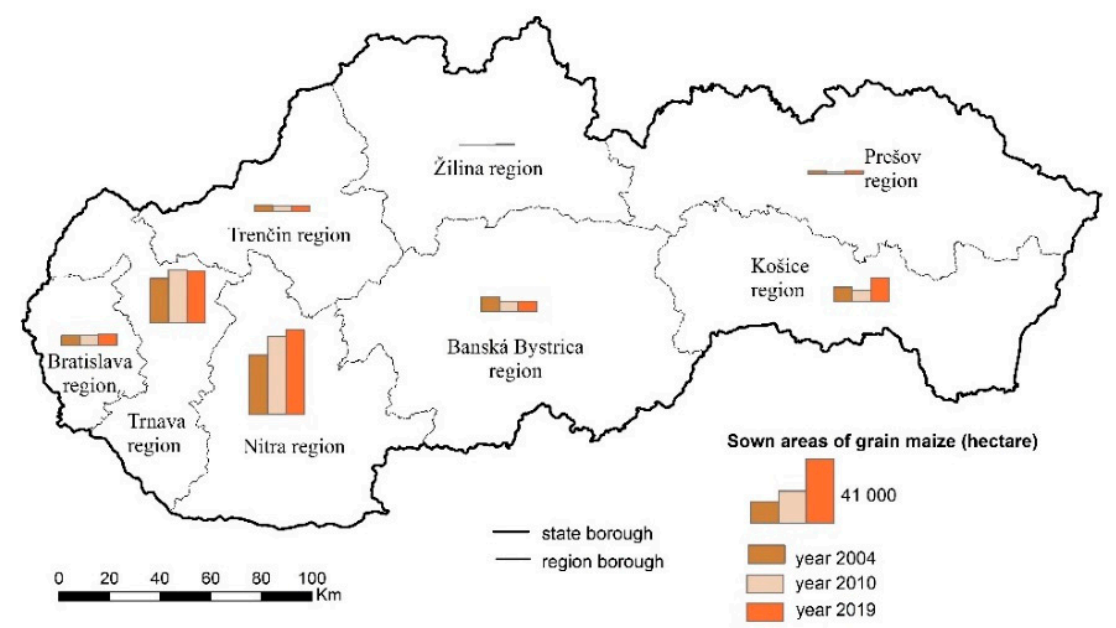

Figure 5. Development of sown areas of grain maize in the regions of SR in 2004, 2010 and 2019 (in ha). Source: [56]; authors' own research.

The Nitra Region grows more than $30 \%$ of the oil-plants. The Košice and Trnava Regions together have a share of approximately $20 \%$. Legumes are mainly grown in the Nitra (a 40\% share in Slovakia's sown areas) and Trnava Regions (a 20\% share) (Figure 6).

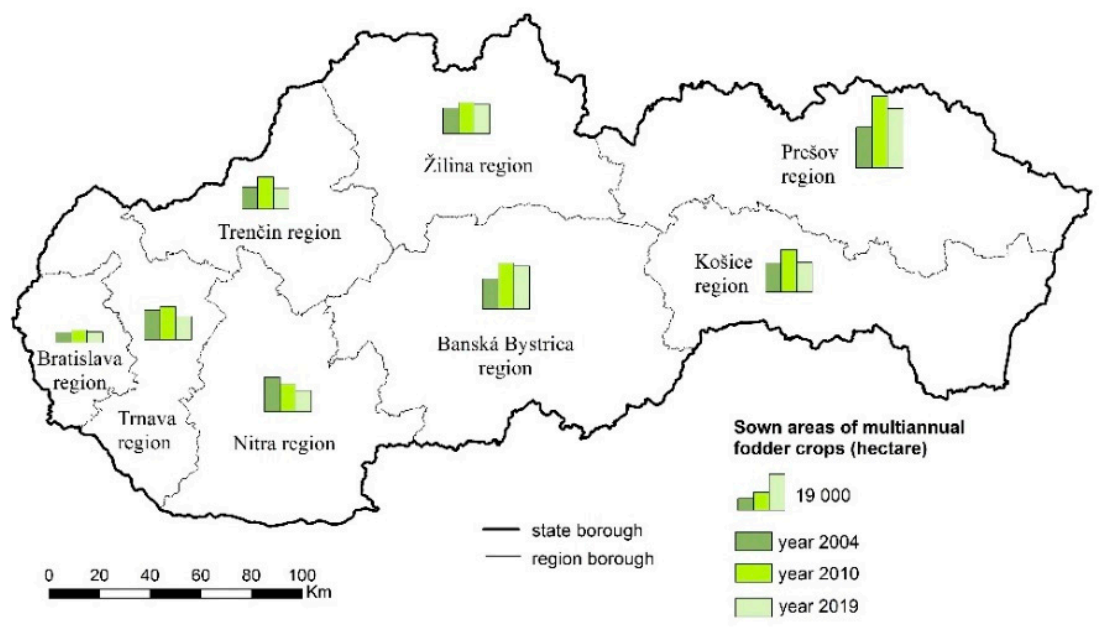

Figure 6. Development of sown areas of multiannual fodder crops in the regions of SR in 2004, 2010 and 2019 (in ha). Source: [56]; authors' own research.

The Prešov (30\%), as well as the Žilina, Trnava and Bratislava Regions, contain the highest shares of sown areas of potatoes (over 10\%) (Figure 7). Currently, the largest growing regions of sugar-beet are situated in western Slovakia (Figure 8). The Nitra and Trnava Regions account for more than $80 \%$ of the sown areas. The regions with the biggest growing areas of vegetables are the Nitra (45\%), Trnava $(20 \%)$ and Banská Bystrica Regions $(18 \%)$. Regions located in the south of Slovakia have the most suitable natural conditions for crop production (Figure 9). The Prešov Region plays the most important role in the growing of multiannual fodder crops; in the sowing structure of Slovakia, it has approximately a 25\% share. The Banská Bystrica, Žilina, Košice and Trenčín Regions together account for over $10 \%$ (Figure 10). 


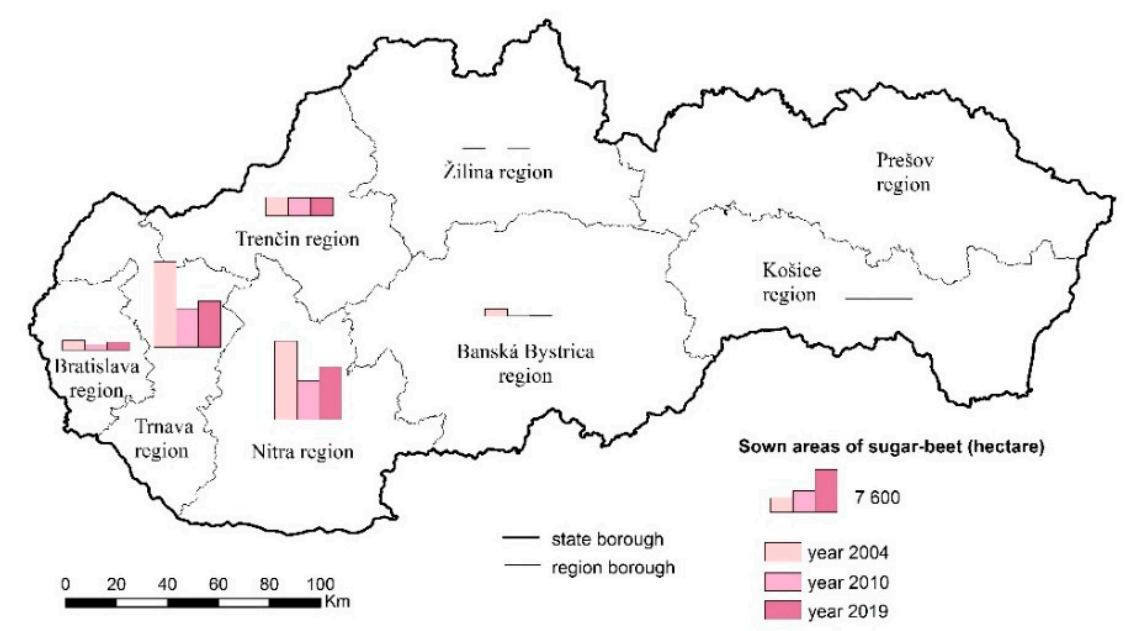

Figure 7. Development of sown areas of sugar-beet in the regions of SR in 2004, 2010 and 2019 (in ha). Source: [56]; authors' own research.

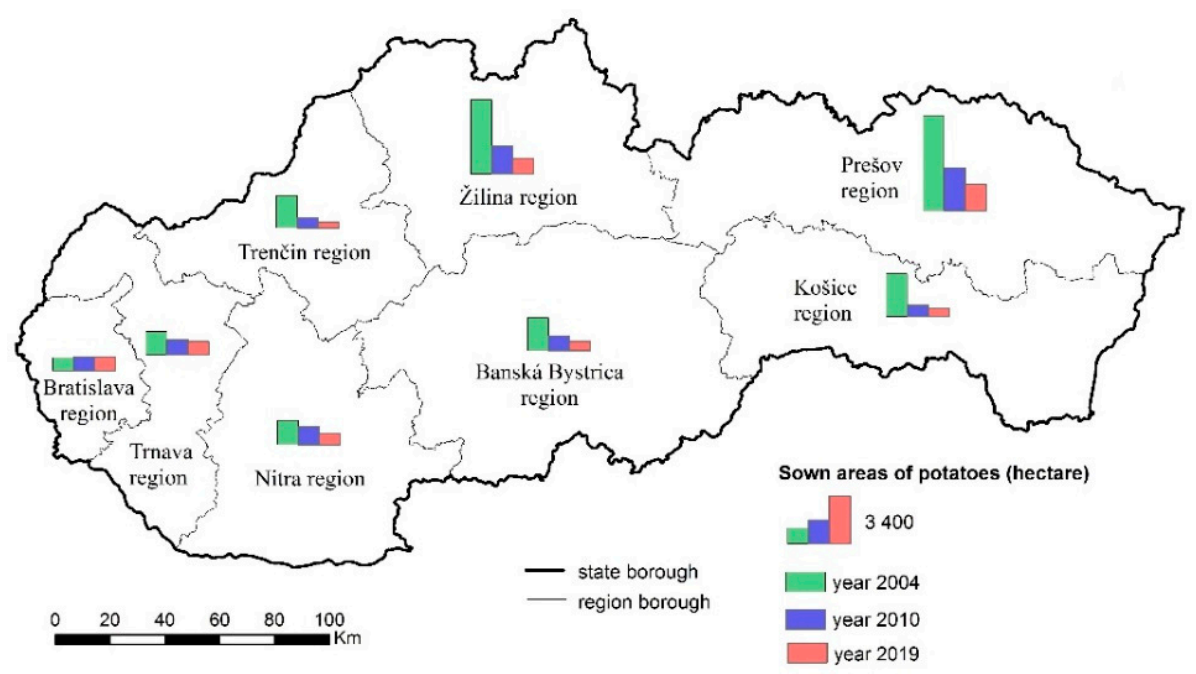

Figure 8. Development of sown areas of potatoes in the regions of SR in years 2004, 2010 and 2019 (in ha). Source: [56]; authors' own research.

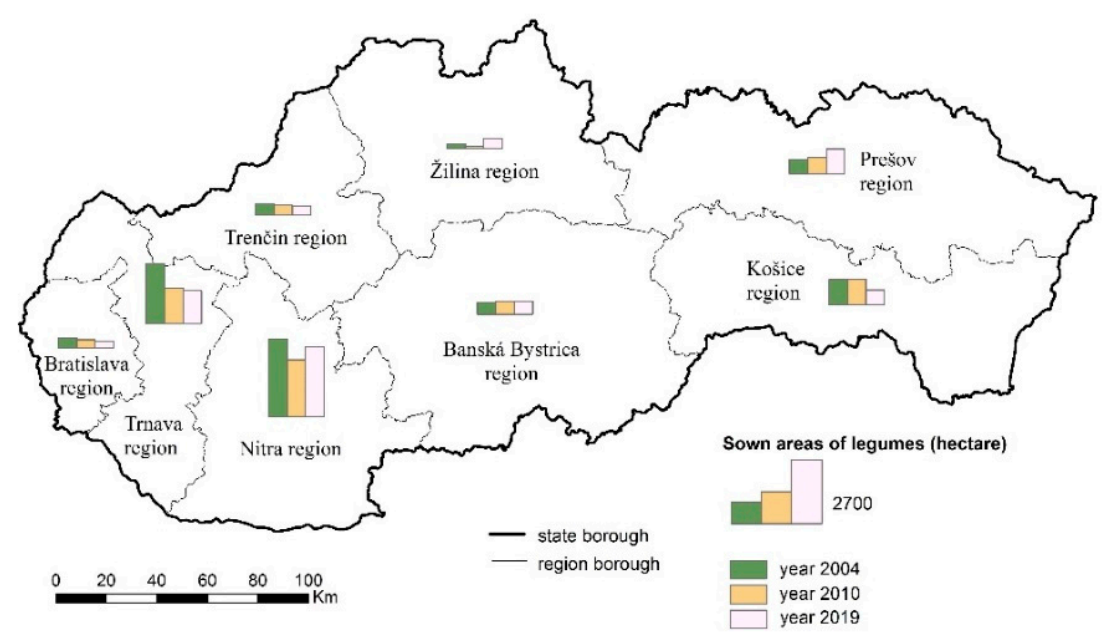

Figure 9. Development of sown areas of legumes in the regions of SR in 2004, 2010 and 2019 (in ha). Source: [56]; authors' own research. 


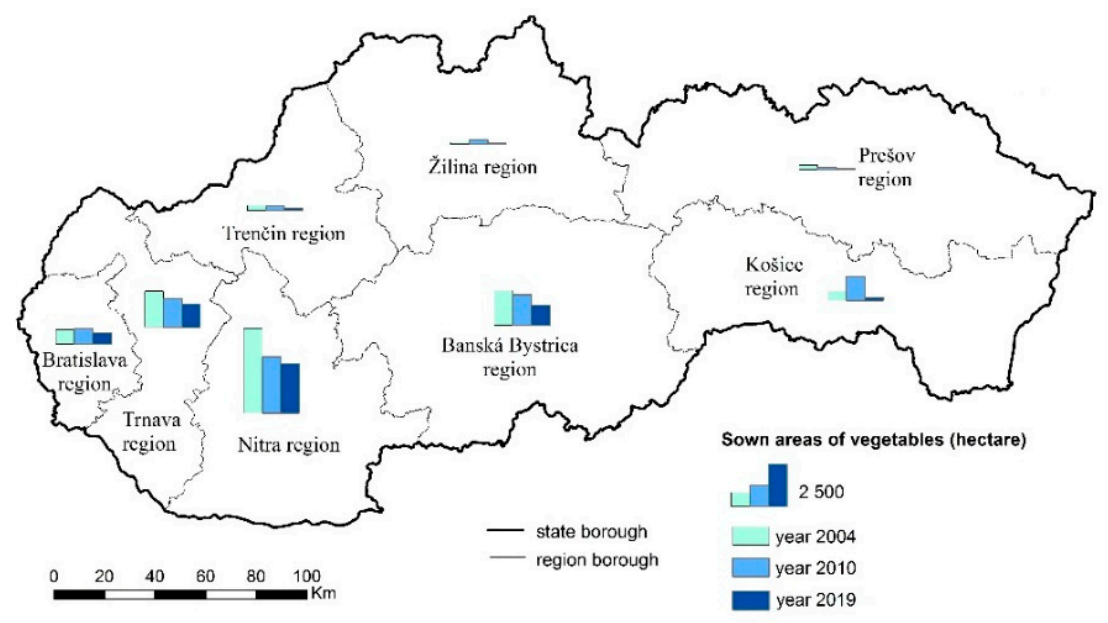

Figure 10. Development of sown areas of vegetables in the regions of SR in 2004, 2010 and 2019 (in ha). Source: [56]; authors' own research.

In the process of finding similarities among Slovak regions with regards to the development of the sown areas of the monitored crops, we worked with multivariate time series, wherein the compared objects were the regions. When searching for an optimal clustering solution, we proceeded analogically, as in the case of clustering crops. The difference is that, for the multivariate time series, it is impossible to apply the SBD metric used in the clustering methods. As to the values of the internal validity indices (sil $=0.64$, $\mathrm{SF}=0.01, \mathrm{CH}=11.83, \mathrm{DB}=0.40, \mathrm{DBstar}=0.40, \mathrm{D}=0.06, \mathrm{COP}=0.24$ ), the two-cluster solution obtained by means of the partitioning method with the soft-DTW metric seems the most fitting. The solution with two clusters with identical representations, as stated at a later stage, proved to also be the most fitting when applying other methods and metrics. Nevertheless, with these criteria of internal validity, we obtained weaker values.

The first cluster contains only two regions, the Nitra and Trnava Regions. These regions adjoin; they are situated in the Danubian Lowland and are the most agriculturally exploited. In the Nitra and Trnava Regions, we see decreasing trends in the sown areas of cereals, potatoes, vegetables and multiannual fodder crops (Figure 11). Given that these regions provide the most suitable natural conditions for crop production, which are convenient for a majority of agricultural crops and Slovakia's granaries, this finding is not particularly pleasing. The sown areas of the other crops monitored within the first cluster (grain maize, oil-plants, legumes and sugar-beet) have tended to increase. 


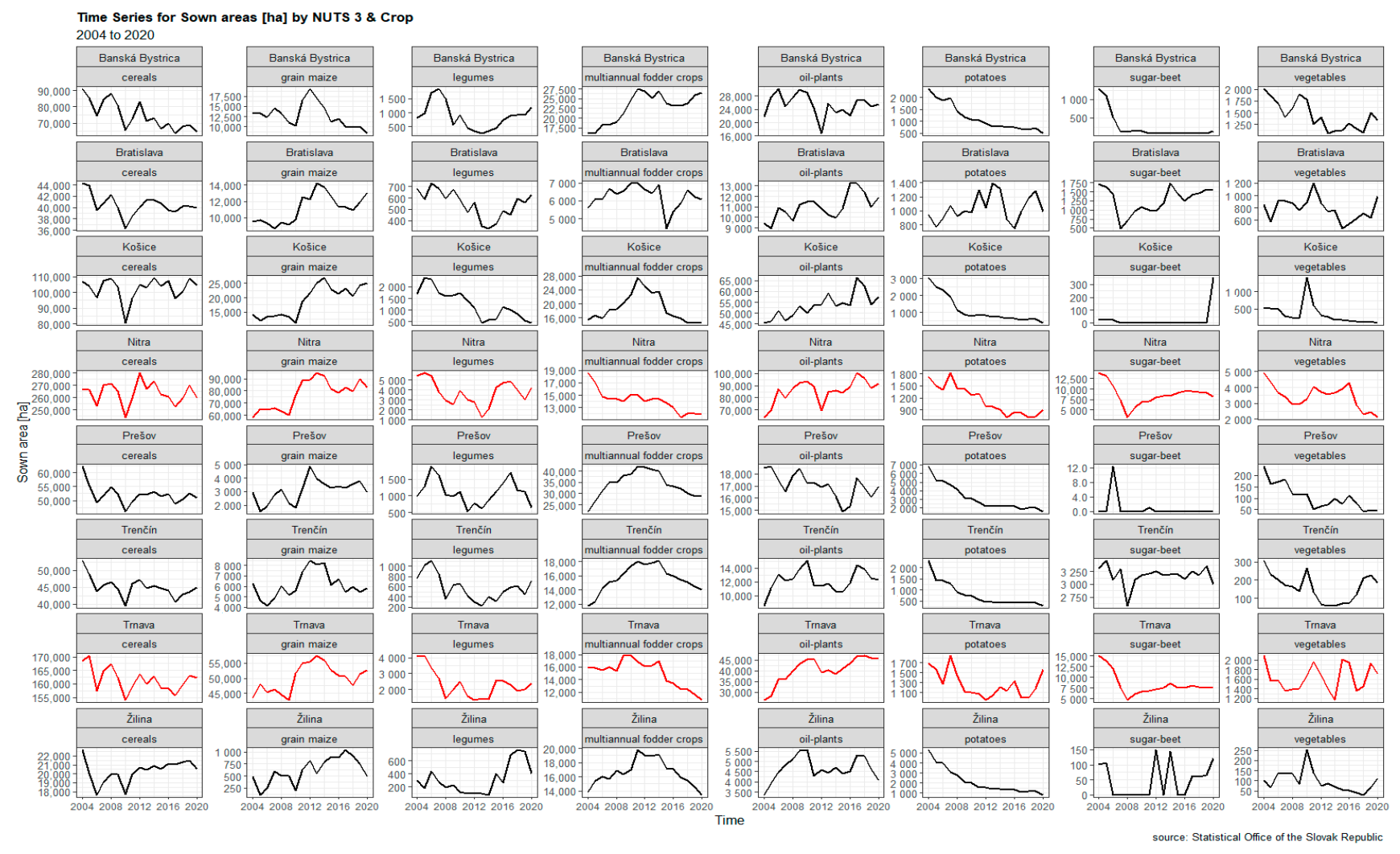

Figure 11. Time series of sown areas of crops in Slovak regions (NUTS 3) by selected crops. Source: [56]; authors' own research.

The second cluster is comprised of the six remaining Slovak regions-Banská Bystrica, Bratislava, Košice, Trenčín, Prešov and Žilina (Figure 11). There was a decrease in the sown area of cereals in all regions belonging to this cluster, apart from the Bratislava and Žilina Regions. An increasing trend in the sown areas was recorded mainly in the Košice and Žilina Regions. In all Slovak regions, the sown areas of oil-plants increased. In the case of legumes, a tendency of increase in the sown areas was more evident in the Žilina and Prešov Regions. The sown areas of sugar-beet are increasing in the Bratislava, Trenčín and Žilina Regions. The sizes of the sown areas of vegetables and potatoes are decreasing in almost all the regions in the second cluster. We observed an increasing trend in vegetable growing, especially in southwestern Slovakia, in the Bratislava and Trenčín Regions. The Bratislava Region also saw an increase in potato growing. The cultivation of multiannual fodder crops was seen to be falling in most regions in the second cluster, except for the Bratislava and Banská Bystrica Regions.

The structural changes related to Slovakia's entering the EU affected crop production. The unequal conditions that Slovak farmers faced with regards to EU subsidies brought about changes in the structure of agricultural production, a drop in the share of livestock production, and an increase in the share of crop production. These changes suggest a potential decline in the competitiveness of the agrarian sector, a threat to the food safety of Slovakia, and a deepening of regional disparities. The numbers of traditional crops have dropped in the sowing structure, and they have been replaced by oil-plants, which, along with grain maize, are also crops used for energy production [55]. Slovakia's crop production is predominantly concentrated in fertile lowlands, which have the most suitable natural conditions for the growing of agricultural crops. Cereal growing is of central importance in crop production, securing food for the population, while cereals belong to the group of crops characterized by lower costs per area unit. Crop production has gradually adapted to the market, and oil-plants grown on arable land have started to prevail, to the disadvantage of other crops. Together with cereals, oil-plants are crops that 
are not labor-intensive and have a lower added value. Slovakia faces a serious problem with workforce, and this is why the farms focus more and more on crops that eliminate manpower. These crops are grown on large areas using modern technology and processes that reduce manpower.

Agricultural land in Slovakia is mainly farmed by big agricultural enterprises (acreage over 500 ha), and these focus predominantly on the growing of large-scale area crops, i.e., crops of general production (cereals and oil-plants). Specialized crop production (the growing of vegetables, fruit, grapes, potatoes, legumes) should be left chiefly in the hands of self-employed farmers. However, these are increasingly focusing on the same crops as big agricultural enterprises. The reason for this is that the growing of crops of specialized production is more labor-intensive and involves higher production costs. Since Slovakia's accession to the EU, farms operating in the production of cereals and oil-plants have dominated in the field of crop production, and their number keeps rising. For instance, the number of farms that focus on oilseed rape is going up. In 2004, it was 1085 farms, and in 2016, the number of farms was 1133. There are few producers of fruit and vegetables, and their numbers keep falling, which can be classified as an aversion to cultivating fruits and vegetables. The number of farms growing vegetables, e.g., cabbage, is decreasing. In 2004, it was 310 farms, and in 2016, their number was 85 [58]. According to the aforementioned findings, the number of farms in Slovakia focusing on crop production commodities that are more labor-intensive is decreasing. On the contrary, in Poland, for example, the number of farms oriented in this way is increasing. The growing consumption of fruit in the country has encouraged an increase in the area of orchards, and demand has become an incentive to adapt the structure of fruit production to market requirements [59]. Additionally, the planned increase in the numbers of cattle and the support for the declining state of livestock production may have a significant impact on the overall structure of the crops grown in Slovakia. In the case of coarse fodder, its higher consumption would be replaced by an increase in the sown areas of multiannual and annual fodder crops grown on arable land.

It can be supposed that the development of bioenergetics and continuing climate change will lead to a higher share of oil-plants grown on arable land. This trend was also confirmed by the clustering methods that we applied in our research paper. In the context of these upcoming trends, there is intense discussion going on in V4 states about the production of technical crops, especially oil-plants. The EU's CAP in the area of biofuels has significantly affected the increase in the production volume of oilseed rape, and the Visegrad Group have gradually become self-sufficient in terms of this commodity. This group are very competitive in the export of the raw commodity into western Europe, yet they lose profits in processing the commodity [60]. Wozniak et al. [61] emphasized in their study the current potential of oilseed rape as a universal multi-purpose crop. It is one of the most popular oil-plants in Europe, as it presents more than $60 \%$ of European output. However, there are a number of risks associated with the growing of crops that are utilized in bioenergetics. According to Vilček et al. [62], their growing on the highest-quality soil in the lowlands may threaten the food safety of the population. The main risk is the utilization of supreme-quality agricultural land. It will be necessary to protect this land for the benefit of the whole society, and to use it mainly for food manufacturing. This change in the commodity structure of crop production may also endanger the production basis of the food processing industry.

Some authors [63] also agree that agricultural land of high quality should firstly be used to provide food for the population, and lower quality land should be used for growing energy crops. The share of energy crops grown on arable land in Poland is $11.1 \%$. The cultivation of energy crops represents a new source of increased income for farmers, while the cultivation of traditional crops is unprofitable [64].

In addition to the long-term effects of climate change, crop production is increasingly being affected by extreme weather conditions (e.g., drought, extreme temperatures, frost, hail, heavy rains, floods). Several studies confirm that farmers use different strategies to mitigate expected risks. In addition to financial instruments, farmers respond to 
these events via crop diversification, which, in addition to economic benefits, also brings environmental benefits [65-67].

On the basis of the time series analyses of the sown areas of selected crops at the level of SR over the 2004-2020 period, which indicate future tendencies in crop production in Slovakia, we can confirm preferences for certain crops, especially oil-plants, cereals, and grain maize. In the coming years, specialized crop production should be increasingly promoted, i.e., the production of fruit, grapes, vegetables, legumes and potatoes. The government aid flowing into this sector would increase Slovakia's self-sufficiency in food economics, and would also contribute to increasing employment in rural areas of Slovakia [2]. Slovakia is currently self-sufficient in terms of food to a level of approximately $40 \%$. It is vital to increase the degree of self-sufficiency in crop cultivation and in the manufacturing of products, in which Slovakia used to be self-sufficient. The next big issue is that Slovakia exports mainly raw materials and imports finished products. The added value in the form of employment is thus generated abroad. It is therefore important to ensure an efficient connection between agriculture and the food industry. The European Union is trying to formulate the uniform Common Agricultural Policy in all EU states. It is, however, influenced by the state policies of individual countries, among other factors.

\section{Conclusions}

The contribution of this study is the conclusions it obtained using statistical methods in monitoring the development tendencies of the most important crops, which confirmed that agricultural development in regions of Slovakia with favorable natural conditions is more oriented towards crop production. Therefore, the first cluster included typical agricultural regions of Slovakia-Nitra and Trnava. These are characterized by similar developments in the time series of crop sowing areas, and also by similarly sized sowing areas. They are the regions with the largest area of agricultural and arable land. The second cluster includes other counties that, despite having different physical and geographic conditions, belong to the same cluster. For some crops, similar trends can be observed in all counties, e.g., cereals, legumes, grain maize, oilseeds and potatoes. However, there are crops, such as multiannual fodder crops, sugar-beet and vegetables, for which the time series trends of crop area in the counties are more divergent, and therefore these crops have influenced the formation of the two clusters. Oilseeds, grain maize and multiannual fodder crops display similar trends in sown area, are the crops that receive the most subsidy support, have high market demand, and are used for industrial purposes. The crop cluster of potatoes, legumes and vegetables is characterized by a declining trend in sown area and lacks subsidization, which may also be a consequence of the continuing reduction in the labor force in this sector. The steady increase in the share of crops sown for biofuel production is acting as a hidden risk factor, changing the commodity structure of crop production, which outwardly appears to be a positive step, but is in fact a threat to the production base for the food industry and risks overpowering the country's food security requirements and needs. This is a global problem that affects several countries in the European Union.

The results of this study suggest that in the next programming period of 2021-2027, Slovakia will need to change the sectoral structure of its agricultural industry, which is currently based predominantly on crop-based production, a fact that negatively affects job creation in rural areas. Prosperous livestock production means higher rural employment and the exploitation of the potential of permanent grassland. The current direction of agricultural development is having a negative impact on the development and competitiveness of agriculture and food self-sufficiency in Slovakia.

Our analysis shows that the support for special crop production by the state, the diversification of crop cultivation, the achieving of the highest possible self-sufficiency in the production of post-harvest crops, and the securing of the quality and safety of food for the population through domestic production, are the necessary strategic goals of Slovak agriculture. Growing crops with higher added value has a positive impact on the structure 
of crop production and on the creation of new jobs in agriculture. Vegetable production should take greater account of consumer demands, and produce more products labeled "organic", "local" and "fair trade".

The EU's new, formative CAP should be directed towards fairer subsidy support in all EU Member States. Agricultural production will increasingly depend on demand, and overall, will reflect the market situation and the impact of the CAP.

Our future research will focus on investigating trends in the cultivation of crops for different purposes (food, industrial, feed and biofuel production) and their use in the finalization of raw materials into finished foods and/or products. Research along these lines would also be of interest in the broader European region.

Author Contributions: Conceptualization, J.N. and L'.R.; methodology, J.N. and L'.R.; software, L'.R.; validation, J.N. and L'.R.; formal analysis, J.N.; resources, J.N.; data curation, J.N. and L'.R.; writingoriginal draft preparation, J.N. and L'.R.; writing — review and editing, J.N. and L'.R.; visualization, J.N. and L'.R. All authors have read and agreed to the published version of the manuscript.

Funding: This paper was supported by Scientific Grant Agency VEGA project No 1/0880/21 “Transformation of the Nitra Region in Changing Socio-economic Conditions with Special Focus to the Effects of the COVID-19 Pandemics". This work was supported by the Slovak Research and Development Agency under the Contract no. APVV-18-0185.

Institutional Review Board Statement: Not applicable.

Informed Consent Statement: Not applicable.

Data Availability Statement: The data presented in this study are available on request from the corresponding author. The data are not publicly available due to privacy reasons.

Conflicts of Interest: The authors declare no conflict of interest.

\section{References}

1. Némethová, J.; Dubcová, A.; Kramáreková, H. The Impacts of the European Union's common agricultural policy on agriculture in Slovakia. Morav. Geogr. Rep. 2014, 22, 51-64. [CrossRef]

2. Némethová, J.; Svobodová, H.; Křejčí, O.; Věžník, A. Development of Crop Production in the Slovakia and Czechia after the Year 2004 in Comparison with V4 Countries. Bull. Geogr. Socio-Econ. Ser. 2020, 50, 7-22. [CrossRef]

3. Grznár, M.; Szabo, Ĺ.; Jankelová, N. Agrárny sektor Slovenskej republiky po vstupe do Európskej únie. Econ. Časopis. 2009, 57, 903-917.

4. Szabo, L.; Grznar, M.; Zelina, M. Agricultural performance in the V4 countries and its position in the European Union. Agric. Econ. Czech. 2018, 64, 337-346. [CrossRef]

5. Jankacká, K.; Lincényi, M. Vývoj ekonomických ukazovatel’ov pol'nohospodárskych podnikov. Ekon. Agric. 2013, 13, 33-44.

6. Ministry of Agriculture and Rural Development of the Slovak Republic. Zelená Správa 2017; Ministry of Agriculture and Rural Development of the Slovak Republic: Bratislava, Slovakia, 2018.

7. Serenčéš, R.; Mučaji, I. Spoločná pol'nohospodárska politika EÚ a SR. In Proceedings of the Reviewed Articles of 13th International Scientific Conference, International Scientific Days 2014: Improving Performance of Agriculture and the Economy: Challenges for Management and Policy, High Tatras, Slovakia, 21-23 May 2014.

8. Bičík, I.; Jančák, V. Transformační Procesy v Českem Zemědelství po Roce 1990; Univerzita Karlova: Praha, Czech Republic, 2005.

9. Némethová, J.; Midler, M.; Civáň, M. Development tendencies in crop production in Slovakia after 2004-Regional differentiations. J. Cent. Eur. Agric. 2018, 19, 245-269. [CrossRef]

10. Věžník, A.; Král, M.; Svobodová, H. Agriculture of the Czech Republic in the 21 st century: From productivism to postproductivism. Quaest. Geogr. 2013, 32, 7-14. [CrossRef]

11. Svobodová, H. Vývoj zemědělské výroby v České republice pod vlivem společné zemědělské politiky EÚ. Acta Reg. Environ. 2011, 8, 15-21.

12. Scrieciu, S. Socioeconomic and Environmental Impacts on Agriculture in the New Europe: Post-Communist Transition and Accession to the European Union; Routledge: London, UK, 2011. [CrossRef]

13. Chrastinová, Z.; Krížová, S.; Zbranek, P. Comparison of production performance of agriculture in EU countries. Ekon. Agric. 2017, $17,53-76$.

14. Lacko-Bartošová, M.; Buday, Š. Global challenges for sustainable agriculture and rural development in Slovakia. J. Cent. Eur. Agric. 2013, 14, 263-278. [CrossRef]

15. Sapolaite, V.; Veveris, A.; Volkov, A.; Namiotko, V. Dynamics in the Agricultural Sectors of the Baltic States: The Effects of the Common Agricultural Policy and Challenges for the Future. Montenegrin J. Econ. 2019, 15, 211-223. [CrossRef] 
16. Boltižiar, M.; Olah, B.; Gallay, I.; Gallayová, Z. Transformation of the Slovak cultural landscape and its recent trends. In Proceedings of the 17th International Symposium on Landscape Ecology, Institute of Landscape Ecology SAS, Landscape and Landscape Ecology, Bratislava, Slovakia, 27-29 May 2016.

17. Fanelli, R.M. The interactions between the structure of the food supply and the impact of livestock production on the environment. A multivariate analysis for understanding the differences and the analogies across European Union countries. Qual. Access Success. 2018, 19, 131-139.

18. Fanelli, R.M. A new classification of European Union regions: A decision support tool for policymakers. Span. J. Agric. Res. 2019, 17. [CrossRef]

19. Fanelli, R.M. The (un)sustainability of the land use practices and agricultural production in EU countries. Int. J. Environ. Stud. 2019, 1-22. [CrossRef]

20. Jäntschi, L.; Bolboaca, S.D.; Stoenoiu, C.E. National trends on agricultural crops production: Cluster analysis. Bull. USAMV-CN. 2007, 63, 194-202.

21. Lazíková, J.; Bandlerová, A.; Rumanovská, L'; Takáč, I.; Lazíková, Z. Crop Diversity and Common Agricultural Policy-The Case of Slovakia. Sustainability 2019, 11, 1416. [CrossRef]

22. Svobodová, H.; Věžník, A. Impacts of the Common Agricultural Policy of the European Union in the Vysočina region (Czech Republic) by the view of the farmers. J. Cent. Eur. Agric. 2011, 12, 733-743. [CrossRef]

23. Věžník, A.; Konečný, O. Agriculture of the Czech Republic after accession to the EU: Regional differentiation. Morav. Geogr. Rep. 2011, 19, 50-60.

24. Kroupová, Z.; Trnková, G. The analysis of economic results differences of aricultural holdings specialized in plant production in the Czech Republic. J. Cent. Eur. Agric. 2014, 15, 322-334. [CrossRef]

25. Kotyza, P.; Slaboch, J. Food Self Suffi ciency in Selected Crops in the Czech Republic and Poland. Acta Univ. Agric. Silvic. Mendel. Brun. 2014, 62, 1329-1341. [CrossRef]

26. Todorová, S. Bulgarian agriculture in the conditions of the EU Common Agricultural Policy. J. Cent. Eur. Agric. 2016, 17, 107-118. [CrossRef]

27. Skarżyńska, A.; Abramczuk, L.; Jabłoński, K. Impact of growing costs on the profitability of crop production in Poland in the mid-term perspective. J. Cent. Eur. Agric. 2016, 17, 119-138. [CrossRef]

28. Maye, D. Reassessing agricultural multifunctionality in the context of food security, climate change and the new land use debate. In New Rural Spaces. Towards Renewable Energies, Multifunctional Farming, and Sustainable Tourism; Frantál, B., Martinát, S., Eds.; Institute of Geonics, Academy of Sciences of the Czech Republic: Brno, Czech Republic, 2013; pp. 60-71.

29. Nazzaro, C.; Marrota, G. The Common Agricultural Policy 2014-2020: Scenarios for the European agricultural and rural systems. Agric. Food Econ. 2016, 16, 4403. [CrossRef]

30. Spišiak, P.; Kusendová, D.; Pavličková, K.; Halás, M.; Kolény, M.; Zubriczký, G.; Švoňavec, M.; Hurbánek, P.; Pal'úch, T.; Labuda, M. Agrorurálne Štruktúry Slovenska po Roku 1989; Geo-Grafika: Bratislava, Slovakia, 2005.

31. Shucksmith, M.; Thomson, K.J.; Roberts, D. CAP and the Regions: The Territorial Impact of Common Agricultural Policy; CABI Publishing: Wallingford, CT, USA, 2005. Available online: http://books.google.at/books?id=R000DK-1cfIC\&pg=PA149\&sig= gQNd558qBEe2-DRqo0tzHyqNg (accessed on 6 March 2021).

32. Râmniceanu, I.; Ackrill, R. EU rural development policy in the new member states: Promoting multifunctionality. J. Rural Stud. 2007, 23, 416-429. [CrossRef]

33. Rizzo, F. Approaching Multifunctionality by a 'Normative View': Finnish Farmers' Visions on Contemporary Agriculture. Eur. Countrys. 2016, 8, 16-32. [CrossRef]

34. Sadowski, A.; Czubak, W. The priorities of rural development in the EU countries in years 2007-2013. Agric. Econ. Czech. 2013, 59, 58-73. [CrossRef]

35. Konečný, O. Spatial polarization of agriculture of Czechia during the integration into the European Union. Geografie 2017, 122, 257-280. [CrossRef]

36. Hrabák, J. The regional differentiation of the environmental aspects of agricultural multifunctionality in Czechia. In Proceedings of the International Scientific Conference Region in the Development of Society, Brno, Czech Republic, 23 October 2014; pp. 308-318. Available online: http:/ / www.icabr.com/respo/RESPO_2014.pdf (accessed on 27 May 2021).

37. Greslova, P.; Stych, P.; Salata, T.; Hernik, J.; Knižková, I.; Bičik, I.; Jeleček, L.; Prus, B.; Noszczyk, T. Agroecosystem energy metabolism in Czechia and Poland in the two decades after the fall of communism: From a centrally planned system to market oriented mode of production. Land Use Policy 2019, 82, 807-820. [CrossRef]

38. Zaušková, L'.; Midriak, R.; Krajčovič, V. Dopady transformačného obdobia a obdobia po vstupe Slovenska do EÚ na zmeny využívania pol'nohospodárskej krajiny. Ekon. Agric. 2012, 17, 98-106.

39. Zaušková, L'. Problémy rozvoja pol'nohospodárskej krajiny v Slovenskej republike. In Súčasný stav a Najbližši Vývoj Pôdneho Fondu na Slovensku; Zborník Referátov z Vedeckého Sympózia k 80. Výročiu Narodenia Prof. Rudolfa Šályho, DrSc., Konaného dňa 1. Júna 2007 v Turčianskych Tepliciach; Národné Lesnícke Centrum—Lesnícky Výskumný Ústav: Zvolen, Slovakia, 2007; pp. 49-53.

40. Fu, T. A review on time series data mining. Eng. Appl. Artif. Intell. 2011, 24, 164-181. [CrossRef]

41. Liao, T.W. Clustering of time series data-survey. Pattern Recognit. 2005, 38, 1857-1874. [CrossRef]

42. Paparrizos, J.; Gravano, L. K-Shape: Efficient and accurate clustering of time series. In Proceedings of the 2015 ACM SIGMOD International Conference on Management of Data, Melbourne, VIC, Australia, 31 May-4 June 2015; pp. 1855-1870. [CrossRef] 
43. Sardá-Espinosa, A. Comparing Time-Series Clustering Algorithms in R Using the Dtwclust Package. Available online: https: / / www.researchgate.net/publication/312159618 (accessed on 6 March 2021).

44. Aghabozorgi, S.; Shirkhorshidi, A.S.; Wah, T.Y. Time-series clustering-A decade review. Inf. Syst. 2015, 53, 16-38. [CrossRef]

45. Sardá-Espinosa, A. Package dtwclust: Time Series Clustering along with Optimizations for the Dynamic Time Warping Distance. R Package Version 5.4.0. 2019. Available online: https:/ /CRAN.R-project.org/package=dtwclust (accessed on 6 March 2021).

46. Rousseeuw, P.J. Silhouettes: A graphical aid to the interpretation and validation of cluster analysis. J. Comput. Appl. Math. 1987, 20. [CrossRef]

47. Arbelaitz, O.; Gurrutxaga, I.; Muguerza, J.; Perez, J.M.; Perona, I. An extensive comparative study of cluster validity indices. Pattern Recognit. 2013, 46, 243-256. [CrossRef]

48. Saitta, S.; Raphael, B.; Smith, I.F. A bounded index for cluster validity. In Proceedings of the International Workshop on Machine Learning and Data Mining in Pattern Recognition, Leipzig, Germany, 18-20 July 2007; pp. 174-187.

49. Kim, M.; Ramakrishna, R.S. New indices for cluster validity assessment. Pattern Recognit. Lett. 2005, 26, 2353-2363. [CrossRef]

50. R Core Team. R: A Language and Environment for Statistical Computing; R Foundation for Statistical Computing: Vienna, Austria, 2018; Available online: https:/ / www.R-project.org (accessed on 6 March 2021).

51. Wickham, H. ggplot2: Elegant Graphics for Data Analysis; Springer: New York, NY, USA, 2009.

52. Žarnovičan, H.; Kollár, J.; Falt’an, V.; Petrovič, F.; Gábor, M. Management and Land Cover Changes in the Western Carpathian Traditional Orchard Landscape in the Period after 1948. Agronomy 2021, 11, 366. [CrossRef]

53. Feszterová, M.; Hudec, M. Evaluation of humus content in soil based on environmental and ecological factors in selected areas of central Slovakia. In Proceedings of the 26th International Geographical Conference "Geographical Aspects of Central Europe: Slovakia and Czechia-25 Years on the Political Map of the World", Nitra, Slovakia, 10-11 October 2018; pp. 44-60. Available online: http:/ / www.kgrr.fpv.ukf.sk/en/images/Geographical\%20Information_2_2018.pdf (accessed on 27 May 2021).

54. Blaas, G.; Božík, M.; Brodová, M. Úloha koncepcie multifunkčnosti pol'nohospodárstva v reforme spoločnej pol'nohospodárskej politiky. In Proceedings of the Multifunkčné Postavenie a Trvalo Udržatel'ný Rast Pol'nohospodárstva a Lesníctva: Zborník Referátov a Diskusných Príspevkov z Vedeckej Rozpravy XXIX, Valného Zhromaždenia Členov Slovenskej Akadémie Pôdohospodárskych Vied, Nitra, Slovakia, 5 December 2006; pp. 6-15.

55. Chrastinová, Z.; Uhrinčat'ová, E. Slovak agriculture in the context of the European Union countries. Ekon. Agric. 2014, 14, 1-28.

56. Štatistický úrad Slovenskej Republiky. 2020. Available online: http:/ / www.statistics.sk (accessed on 6 March 2021).

57. Blažík, T.; Falt’an, V.; Tarasovičová, Z.; Saksa, M. Zmeny využitia zeme vybraných okresov rôznych pol'nohospodárskych oblastí v kontexte prebiehajúcich transformačných procesov. Geogr. Časopis. 2011, 63, 301-323.

58. Tóth, M. Vplyv Integrácie a Globalizácie na Štruktúru a Podnikatel'ské Riziko v Pol'nohospodárstve na Slovensku; SPU: Nitra, Slovakia, 2019; p. 107. [CrossRef]

59. Wojcik, M.; Traczyk, A. Changes in the Spatial Organisation of Fruit Growing at the Beginning of the 21st Century: The Case of Grojec Poviat (Mazovia Voivodeship, Poland). Quaest. Geogr. 2017, 36, 71-84. [CrossRef]

60. Slaboch, J.; Kotyza, P. Are V4 countries competitive in production of main oil-bearing crops in the perspective of production self-sufficiency and foreign trade development? In Proceedings of the Agrarian Perspectives XXIV: Global Agribusiness and the Rural Economy, Prague, Czech Republic, 16-18 September 2015; pp. 363-375.

61. Wozniak, E.; Waszkowska, E.; Zimny, T.; Sowa, S.; Twardowski, T. The Rapeseed Potential in Poland and Germany in the Context of Production, Legislation, and Intellectual Property Rights. Front. Plant Sci. 2019, 10, 1423. [CrossRef]

62. Vilček, J.; Sopko, P.; Krušková, Z. Vhodnost' pol'nohospodárskej krajiny pre pestovanie plodín na energetické účely. Folia Geogr. 2012, 19, 235-257.

63. Jezierska-Thöle, A.; Rudnicki, R.; Kluba, M. Development of energy crops cultivation for biomass production in Poland. Renew. Sustain. Energy Rev. 2016, 62, 534-545. [CrossRef]

64. Kołodziejczak, A.; Rudnicki, R. Spatial Diversification of Energy Crops in Polish Agriculture: A Study of Plantation Concentration Based on Local Indicators of Spatial Association (Lisa). Quaest. Geogr. 2017, 36, 49-56. [CrossRef]

65. Lancaster, N.A.; Torres, A.P. Investigating the Drivers of Farm Diversification among US Fruit and Vegetable Operations. Sustainability 2019, 11, 3380. [CrossRef]

66. Latruffe, L.; Fogarasi, J.; Desjeux, Y. Efficiency, productivity and technology comparison for farms in Central and Western Europe: The case of field crop and dairy farming in Hungary and France. Econ. Syst. 2012, 36, 264-278. [CrossRef]

67. Huang, J.; Jiang, J.; Wang, J.; Hou, L. Crop Diversification in Coping with Extreme Weather Events in China. J. Integr. Agric. 2014, 13, 677-686. [CrossRef] 